\title{
Model-based scenarios of Mediterranean droughts
}

\author{
M. Weiß, M. Flörke, L. Menzel, and J. Alcamo \\ Center for Environmental Systems Research, University of Kassel, Kurt-Wolters-Str. 3, 34109 Kassel, Germany \\ Received: 1 March 2007 - Revised: 5 June 2007 - Accepted: 21 October 2007 - Published: 2 November 2007
}

\begin{abstract}
This study examines the change in current 100year hydrological drought frequencies in the Mediterranean in comparison to the 2070s as simulated by the global model WaterGAP. The analysis considers socio-economic and climate changes as indicated by the IPCC scenarios A2 and B2 and the global general circulation model ECHAM4. Under these conditions today's 100-year drought is estimated to occur 10 times more frequently in the future over a large part of the Northern Mediterranean while in North Africa, today's 100 -year drought will occur less frequently. Water abstractions are shown to play a minor role in comparison to the impact of climate change, but can intensify the situation.
\end{abstract}

\section{Introduction}

The diversity and complexity of drought impacts and the low level of preparedness for future events is a point of global concern. Entries in the EM-DAT database (Guha-Sapir et al., 2004) show that total reported global economic losses due to droughts rank fourth in the list, following those reported for earthquakes, floods and windstorms. Two major droughts in Australia in the last twenty years have resulted in great financial losses, with the damage of the 1991-1995 drought amounting to an estimated $\$ 5$ billion. Approximately 8 million of Ethiopia's 60 million people are at risk due to drought (UNICEF, 2000). Large areas of Europe have been affected by droughts over the past 50 years (EEA, 2001). Water shortages and poor harvests during the droughts of the early 1990s exposed an acute vulnerability of the Mediterranean region to climatic extremes. The latest drought of 2003 affected most of continental Europe. The ongoing debate about climate change and its potential effects on the frequency and severity of extreme climatic events is adding further to the concerns of scientists and decision makers, because observed changes have shown that drought events are already on the rise (IPCC, 2001; Guha-Sapir et al., 2004).

Correspondence to: $\mathrm{M}$. Weiß

(weiss@cesr.de)

\section{Purpose of the study}

This study will, explicitly for the Mediterranean Region, examine whether the upward trend of droughts (IPCC, 2001), as described above, is likely to continue in the future, examining drought frequency as the main indicator. It will investigate the impacts of global change, including climate and socio-economic changes on future hydrological drought frequencies using two of the IPCC global emission scenarios, A2 and B2 (IPCC, 2000). These emission scenarios were constructed to explore future global developments of society and environment. Scenario A2 assumes a strong, but regionally oriented economic growth and fragmented technological change with an emphasis on human wealth, while B2 emphasizes the protection of the environment and social equity, but also relies on local solutions to economic, social, and environmental sustainability. Both scenarios represent a world in which the differences between developed and developing countries remain strong.

\section{The WaterGAP model}

The analysis is based on the application of the integrated global water model WaterGAP (Water - Global Assessment and Prognosis). WaterGAP, developed at the Center for Environmental Systems Research at the University of Kassel, Germany, computes current and future water availability and water use. It consists of a global hydrology model to simulate the continental water cycle and a global water use model to simulate anthropogenic impacts on it (Alcamo et al., 2003; Döll et al., 2003).

The hydrology model calculates daily water balances based on climate information on a $0.5^{\circ} \times 0.5^{\circ}$ (geographical latitude and longitude) grid cell basis. For each grid cell, the daily vertical water balance is calculated to determine evapotranspiration, snow and groundwater storage, and surface runoff. With the water use model, water withdrawals for the different sectors household, industry (manufacturing and electricity production) and agriculture (livestock and irrigation) are calculated. Water withdrawals in the domestic and industrial sectors, for example, are calculated by relating

Published by Copernicus Publications on behalf of the European Geosciences Union. 
changes in national income to changes in the amount of water used per person and per unit electricity generated. Structural changes are considered by taking into account an initially increasing water demand due to structural changes in the water use with increasing income (e.g. domestic appliances) followed by an eventual stabilization of water demands at high incomes. Technological change, on the other hand, effects water use by improvements in water use efficiency (Alcamo et al., 2003, 2007). The water use is subtracted from the surface runoff calculated in the hydrological model and discharges are computed for each grid cell. The cell discharge is routed through the respective river basin according to a global drainage direction map (Döll and Lehner, 2002) to form river discharge. The model is calibrated and validated against measured discharges from the Global Runoff Data Center (GRDC, 2004).

Current climatic conditions are represented by the climate normal period, 1961-1990, using CRU data (New et al., 2000). In order to derive future discharge values, WaterGAP is driven by climate change projections (temperature and precipitation) as calculated by the global climate Model ECHAM4 (Roeckner et al., 1996), and by a set of scenario assumptions for changes in human water use (IPCC, 2000) that provide values for e.g. technological and structural changes, population growth rates, economic indicators, etc. Future conditions are represented by the time period 20612090 , referred to as the 2070s.

Döll et al. (2003) showed that WaterGAP simulations are fairly robust for long-term average discharges and to be in reasonable limits for monthly high and low-flow statistics, especially for large river basins $\left(>20000 \mathrm{~km}^{2}\right)$. Lehner et al. (2006) further examined the suitability of WaterGAP to model low flow and droughts. They found a modelling efficiency (which is expressed as the degree of agreement between GRDC observed data with WaterGAP modelling results, where 0 means no agreement and 1 total agreement) of 0.88 for the 100 -year drought deficit volume and a modelling efficiency of 0.79 for monthly $Q_{90}$ (Nash-Sutcliffe coefficients). When looking at specific drought events, magnitude and timing, WaterGAP showed some significant errors and is therefore currently not capable of simulating single events. Relative changes, as well as large-scale low-flow regimes and general drought statistics, however, are captured well (Lehner et al., 2006). The model is used in this study to analyse long-term changes between now (1961-1990) and the future (2061-2090) and not to reproduce point events in exact timing and magnitude.

\section{Droughts}

The Mediterranean climate is characterized by mild wet winters and hot, dry summers. ECHAM4 shows an overall increase in temperature throughout the seasons of approximately 4 degrees Celsius in the B2 scenario and around 6 de- grees Celsius in the A2 scenario for the region South Europe - Northern Africa. Precipitation decreases by around 10\%$20 \%$ in all seasons for the A2 scenario and by about 5\% in all seasons except for summer in the B2 scenario, where a slight increase is projected. The question is what impact these climate changes will have on low flow conditions and drought frequencies.

Per definition, a drought marks a period of abnormally dry weather sufficiently prolonged so that the lack of water causes a serious hydrologic imbalance (such as crop damage, water supply shortage, etc.) in the affected area (McGraw Hill, 2003). It is hence the consequence of a natural reduction in the amount of precipitation received over an extended period of time, usually a season or more in length. Other climatic factors, e.g. high temperatures and winds or low relative humidity, can significantly aggravate the severity of the event. The effects of droughts often accumulate slowly over a considerable period of time and may linger for years after the termination of the event. Therefore, the onset and end of a drought are difficult to determine. Drought is a normal feature of climate and its recurrence is inevitable. It occurs in high, as well as low rainfall areas. Drought is a frequent and often catastrophic feature in semi-arid climates. It is less frequent and disruptive in humid regions and a less meaningful concept for deserts. However, there remains much disagreement within the scientific and policy community about its characteristics. This partly explains the lack of progress in drought management in many parts of the world (Wilhite, 2000).

Drought severity is, on the one hand, dependent on duration, intensity and geographical extent of a specific drought episode. On the other hand it depends on anthropogenic and vegetation demands and can have far-reaching effects on society, economy and environment. Therefore, many disciplinary definitions of droughts exist (Wilhite, 2000). Each discipline incorporates different physical, biological, or socio-economic factors in its definition. For example meteorological drought is defined as an interval of time during which the actual moisture supply falls short of climatically specific moisture supply at a given place (Palmer, 1965). Agricultural drought is defined as a period, in which soil moisture content is inadequate to meet evapotranspirative demands to initiate and sustain crop growth (WMO, 1975). Hydrologic drought is associated with inadequate stream flow, reservoir and lake levels or groundwater recharge. Chronologically, hydrological droughts lag behind the occurrence of meteorological and agricultural droughts (Wilhite, 2000). They can be of greater extent than the initial meteorological drought due to anthropogenic and other influences. This study will examine hydrological drought because it is the last in the chain and includes all other influences, e.g. of anthropogenic or climatic nature. 


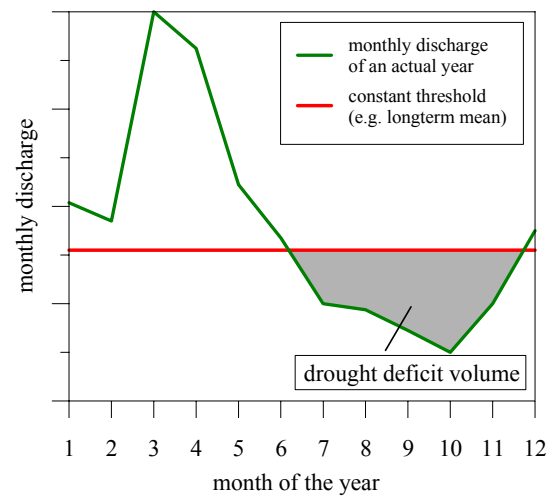

Fig. 1. Discharge hydrograph with constant threshold.

\section{Drought analysis with WaterGAP}

When analysing drought frequencies, a quantitative definition of the starting point and end point of a drought has to be set. A common method is the threshold level method, which has been applied in various studies (Fleig et al., 2006; Lehner et al., 2006; Stahl and Demuth, 1999). The monthly discharge hydrograph is compared to a constant or seasonal threshold value. If the discharge falls below the threshold level, the drought event is defined to start and to last until the discharge curve intersects with the threshold line, i.e. exceeds the threshold value. The specific drought event is, besides its duration in time, further defined by its deficit volume, which is calculated as the area enclosed by the discharge curve and threshold line.

The explicit value of the threshold is of critical importance as it determines the onset and end of each event. If the value is too high, single events can no longer be distinguished but merge into one drought event. If the value is too low, too few droughts are computed and the statistical analysis of extreme values is no longer valid.

Common threshold values are, for example, the $Q_{70}$ or $Q_{90}$ (the flow that is exceeded in $70 \%$ or $90 \%$ percent of the time, respectively), as for example applied by Hisdal and Tallaksen (2000), Arnell (1999), Gottschalka et al. (1997), and Chang and Stenson (1990). Tate and Freenan (2000) and Woo and Tarhule (1994) have, however, shown that the $Q_{70}$ or $Q_{90}$ thresholds are not applicable to intermittent streams where a value between $Q_{5}$ and $Q_{20}$ is suggested. Consequently, the threshold would be basin dependent, which is a disadvantage in meso-scale studies.

As a compromise, Lehner et al. (2006) use the long-term mean discharge as a constant threshold value over time (red line in Fig. 1). This value is rather high and the calculated drought events are characterized by a higher deficit volume and longer duration. Overall, a constant threshold will, by definition, lead to a computed drought in $90 \%$, $70 \%$, or $50 \%$ of the cases, depending on its quantitative value. Yet a drought is defined as a deviation from normal. Therefore,

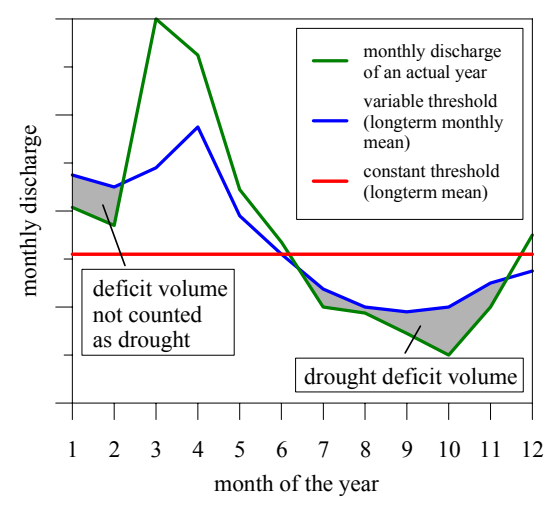

Fig. 2. Discharge hydrograph with combined threshold.

the definition of normal should be more strongly related to the regularly occurring variation of the discharge over time.

Another possibility is, consequently, to apply a variable threshold following the seasonality of the hydrograph, e.g. the long-term monthly means (blue line in Fig. 2). In this case a deficit volume might be calculated for periods when enough water is available in the river, e.g. if elevated discharges during spring due to snowmelt are for some reason lower than usual (grey area for the months January and February in Fig. 2). Since a flow, which is reduced during a particular season, but not absolutely low, is commonly not considered a drought, a combined threshold is used in this study. A deficit volume (grey area in Fig. 2) is calculated for each cell of a river basin as the difference between the long-term (1961-1990) monthly mean cell discharge (blue line in Fig. 2) and the actual monthly cell discharge (green line in Fig. 2) but only for that period of time when the hydrograph falls below the constant threshold of 90 percent of the long-term mean (red line in Fig. 2). The same thresholds are applied to the discharge values under climate scenarios.

Many studies exist on the estimation of return periods, especially the choice of probability distributions (e.g. Bobee, 1975; Kite, 1977; Bobee and Robitaille, 1977; Bobee and Ashkar, 1991; Mitosek et al., 2006) and method for parameter estimation (e.g. Arora and Singh, 1989). In this study the three parameter $(\log )$ Pearson Type III distribution is chosen because it has widely been applied in extreme flow analysis, can be fit to high and low discharge values, and is a common standard at government agencies in the U.S. and Australia (according to IACWD, 1982 and IEA, 1998). The deficit volumes calculated as described above are used to form the annual maximum series (Madsen et al., 1997) by selecting the highest deficit volume each year and ranking these according to size. For each grid cell, either the Pearson III or Log Pearson III distribution is fitted to the annual maximum series based on the underlying data, using the method of moments (Stedinger et al., 1993). The fit of the chosen distribution is checked by an analytical goodness-of-fit test (Kolmogorov-Smirnov test, Rao and Hamed, 2000). 


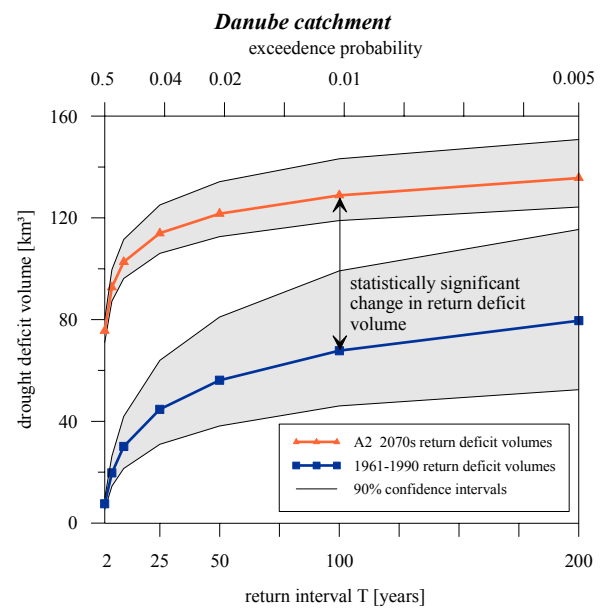

Fig. 3. 1961-1990 and A2 2070s drought frequency curves with $90 \%$ confidence intervals.

The theoretical probability distribution is then used to estimate the probabilities of the hypothetical expected deficit volumes to obtain the drought frequency distribution for $\mathrm{T}=1$ to 200 (drought deficit volumes that are exceeded once every $\mathrm{T}$ years). This procedure is carried out for current conditions, as well as the 2070s. Similar to the 100-year flood, which is widely used by engineers as the reference level for the design of dams, reservoirs, etc. 100-year droughts are further examined. As a result, the change in return period of today's 100 -year drought is calculated by comparing the current situation with the 2070s.

The statistical significance is evaluated by calculating the 90\% confidence intervals (Stedinger et al., 1993) for the estimates of T-year droughts, as exemplary shown in Figs. 3 and 4 for the Danube catchment. The 30-year maximum series is a random sample of the underlying population of annual droughts (expressed in drought deficit volumes) and is used to estimate the frequency curve of that population, which can only be an approximation to the true drought frequency curve (IACWD, 1982). In order to evaluate the statistical significance of the change in drought frequencies, an interval of hypothetical frequency curves is constructed that, with a $90 \%$ degree of confidence, contains the true population frequency curve. Both the record length $\mathrm{N}$ and the specific exceedance probability control the statistical reliability of the estimated frequency curve (IACWD, 1982). Figure 3 shows the current and A2 2070s drought frequency curves and 90\% confidence intervals for the return periods $\mathrm{T}=2$ to 200 . If the two bands (curves accompanied by their $90 \%$ confidence clouds) do not intersect, statistical significance can be assumed, as is the case for the A2 scenario in comparison to today. The change in 100-year drought deficit volume under the B2 scenario for the 2070s for the Danube catchment is not statistically significant because the two bands intersect (Fig. 4). In this case, the return deficit volume calculated for the 2070s could also be a random parameter value of the 1961-1990 population.

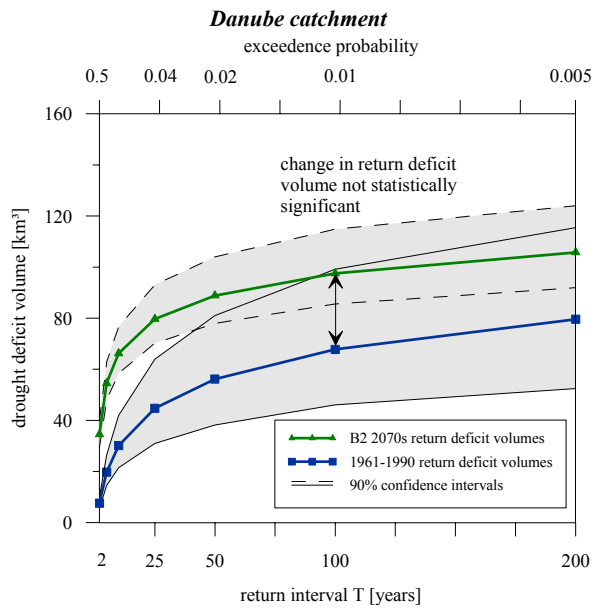

Fig. 4. 1961-1990 and B2 2070s drought frequency curves with $90 \%$ confidence intervals.

\section{Results}

Figures 5 and 6 show future return intervals of current 100year droughts in the 2070s for the IPCC A2 and B2 scenarios. The result for the A2 scenario (Fig. 5) shows very strong increases in frequency over most of Southern Europe, with current 100-year droughts returning once per decade over most of the area. The A2 scenario is based on relatively high greenhouse gas emissions, and therefore has a high rate of climate change. Higher temperatures by itself, or in combination with less precipitation, for example, lead to lower water availability and an increased risk of drought. In $75 \%$ of all grid cells, the change in drought frequency is statistically significant. Areas where statistical significance is uncertain are hatched in Fig. 5.

The B2 scenario (Fig. 6) shows strong increases in the return frequencies of current 100-year droughts for large areas of Northern Spain, the South of France, Northern Italy and Austria. In the long-term projection for the 2070s, current 100-year drought events are calculated to occur once every 10 years, or more frequently. But also the rest of $\mathrm{Eu}-$ rope, especially South-eastern Europe, shows a strong increase in 100-year drought frequency with return intervals of 50 years or more often. In North Africa, only the coast of Algeria faces strong increases in drought frequency, while in the remaining parts current 100-year droughts will occur less frequently. In these areas, precipitation slightly increases, which leads to increasing water availability and decreasing drought intervals. The change in drought frequency is in $69 \%$ of the analysed grid cells statistically significant.

In order to evaluate the impact of the water use sectors on future drought frequencies, the 2070s water consumptions in the industrial, domestic and agricultural sector for the IPCC A2 scenario are combined with current climate, and drought frequencies are calculated, as before. Increasing industrial activities, strong population growth or higher irrigation de- 


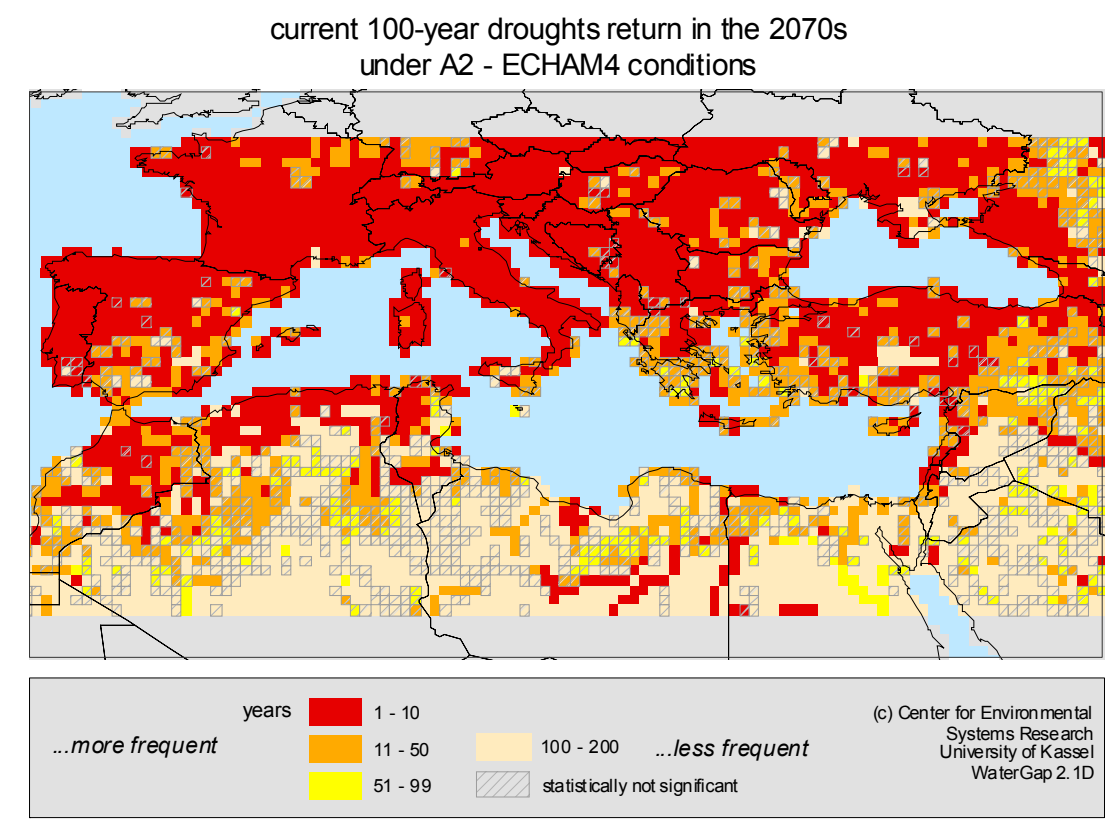

Fig. 5. Return intervals of current 100-year droughts in the 2070s under the IPCC A2 scenario.

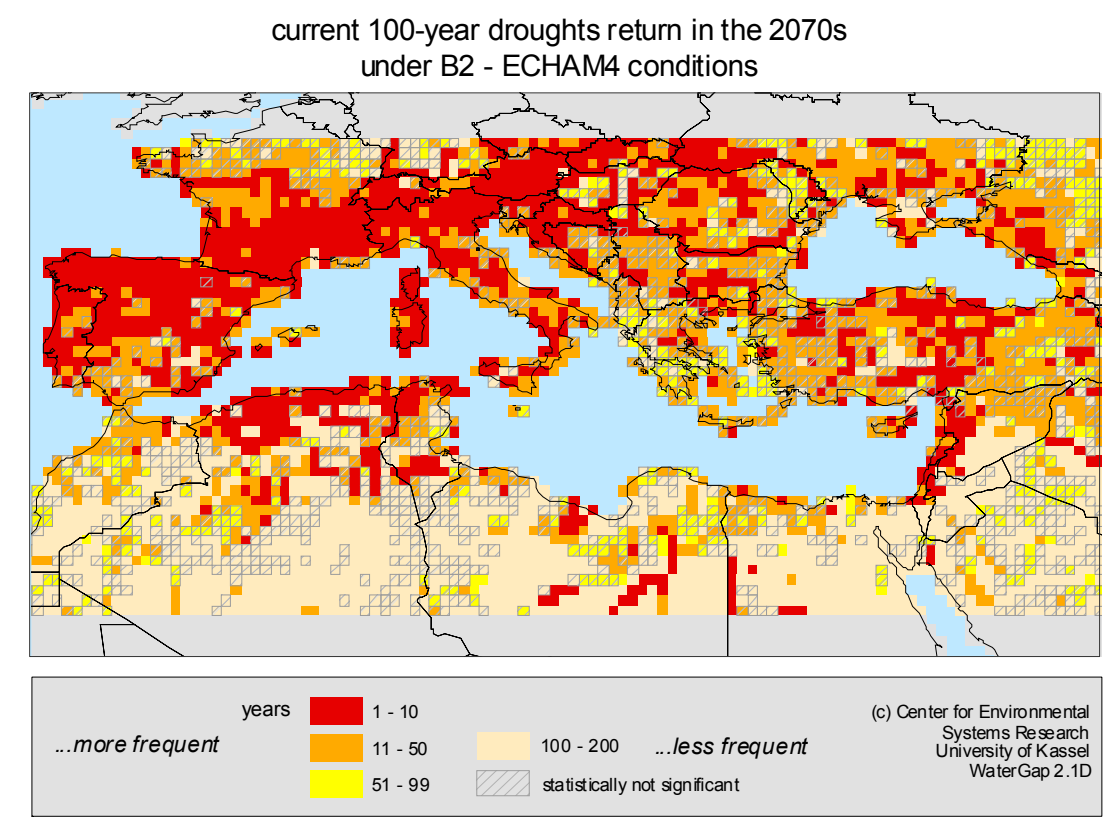

Fig. 6. Return intervals of current 100-year droughts in the 2070s under the IPCC B2 scenario.

mands due to higher temperatures can lead to increasing water demands. If water abstractions in the different sectors fall together with low flow periods, water availability is further reduced and drought conditions can be intensified. In the simulation, the extent of irrigated areas is kept constant to explicitly examine climate-induced changes in irrigation water requirements.

Figure 7 shows that increasing water requirements mainly influence drought frequencies in North Algeria, Morocco, Spain and at the Nile. In these areas, irrigated agriculture plays an important role and elevated water uses follow the projected higher temperatures of the IPCC A2 scenario. Additionally, Africa, the Near East and France are facing population growth rates between $1.1 \%$ and $2 \%$ in the IPCC A2 scenario, which also leads to increasing water uses in the domestic sector. In countries in Central Europe, where the industry is the sector with the highest water use, the projected technological change in the A2 scenario leads to higher water-use efficiencies. Therefore, water uses decrease in these areas and do not influence droughts. The changes in 


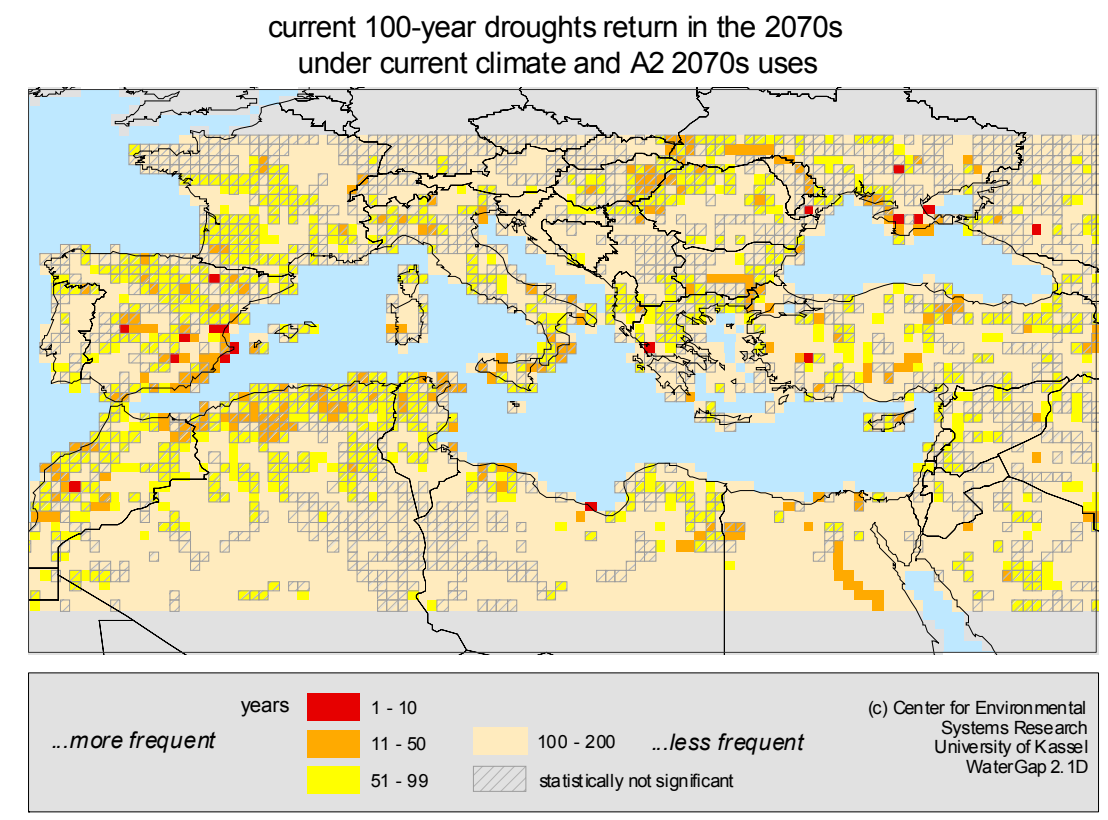

Fig. 7. Impact of water uses under the A 2 scenario on the return interval of current 100 -year droughts.

drought frequencies are in $58 \%$ of all grid cells statistically significant.

Overall, the statistical significance of the change in future return frequencies decreases from the $\mathrm{A} 2$ to the $\mathrm{B} 2$ scenario from $75 \%$ to $69 \%$ and is lowest for the impact of changes in water uses on drought frequencies (58\%), based on $90 \%$ confidence intervals. Statistical significance is uncertain if the 2070s drought frequency band falls within the $90 \%$ confidence interval of the current frequency curve, as the 2070s drought value could also be a random value of the 1961-1990 population. This is for example the case if the difference between the current and 2070s return interval is small (e.g. the current 100year drought returns every 90 years in 2070). The A2 scenario assumes a higher rate of climate change than the B2 scenario and therefore changes in return frequencies are more pronounced, which leads to a higher statistical significance under the A2 scenario. On the other hand, statistical significance is uncertain in areas with generally very low discharges, leaving the calculated drought deficit volumes very small by definition, as for example in North Africa or the near East. It shows that this sort of analysis reaches its limits in arid areas, as a change in drought frequency is less meaningful in the desert.

The reader should be cautious of how to interpret the results of the study in terms of stress and risks for society. According to the method, any shift in low flow occurrence within a year will lead to the calculation of an increased frequency in drought. On the one hand it could be relatively easy for humans to adapt to a low flow, which occurs for example in May in the future as opposed to currently in August. On the other hand this adaptation could be more difficult for aquatic ecosystems that are adapted to a particular seasonal flow regime. In any event the impact of change in drought frequency should be examined carefully.

\section{Conclusions}

The study examined the combined influences of climate and water consumptions on future drought frequencies around the Mediterranean. The results show strong increases in drought frequencies for a belt that stretches from Northern Spain over Southern France towards Northern Italy and Switzerland for the B2 scenario, and strong increase over all of Southern Europe for the A2 scenario. Current 100-year droughts would, under the conditions of the IPCC scenarios, return at least once per decade. In Northern Africa, current 100-year droughts would, except for Northern Algeria, return less frequently. It is shown that climate change has a comparably stronger impact on the change in drought frequency than anthropogenic water uses. Water abstractions can, however, intensify drought conditions. On the other hand, this kind of drought analysis reaches its limits in a dry climate, as drought frequencies cannot increase in deserts and in these areas flows are too low to assume statistical significance of the changes. Overall the study shows a trend towards increasing drought frequencies under both the A2 and B2 scenarios with a statistical significance of $75 \%$ and $69 \%$, respectively, and underlines the vulnerability of the Mediterranean to climate change.

Acknowledgements. This study was performed as part of the GLOWA Jordan River Project (FKZ 01 LW 0502), supported by the German Federal Ministry of Education and Research. The authors wish to thank the reviewers for their valuable comments. 
Edited by: P. Alpert, H. Saaroni, and E. Heifetz

Reviewed by: two anonymous referees

\section{References}

Alcamo, J., Flörke, M., and Märker, M.: Future long-term changes in global water resources driven by socio-economic and climatic changes, Hydrol. Sci. J., 52, 247-275, 2007.

Alcamo. J., Döll, P., Henrichs, T., Kaspar, F., Lehner, B., Rösch, T., and Siebert, S.: Development and testing of the WaterGAP 2 global model of water use and availability, Hydrolog. Sci. J., 48, 317-337, 2003.

Arnell, N. W.: The effect of climate change on hydrological regimes in Europe: a continental perspective, Global Environ. Chang., 9, 5-23, 1999.

Arora, K. and Singh, V. P.: A comparative evaluation of the estimators of the log Pearson type (LP) 3 distribution, J. Hydrol., 105, 19-37, 1989.

Bobee, B.: The log-Pearson type 3 distribution and its applications in hydrology, Water Resour. Res., 14, 365-369, 1975.

Bobee, B. and Ashkar, F.: The Gamma Family and Derived Distributions Applied in Hydrology, Water Resources Publications, Fort Collins, CO, 1991.

Bobee, B. and Robitaille, R.: The use of the Pearson type 3 distribution and log Pearson type 3 distribution revisited, Water Resour. Res., 13, 427-443, 1977.

Chang, T. J. and Stenson, J. R.: Is it realistic to define a 100year drought for water management?, Water Resour. Bull., 26(5), 823-829, 1990.

Döll, P., Kaspar, F., and Lehner, B.: A global hydrological model for deriving water availability indicators: model tuning and validation, J. Hydrol., 270, 105-134, 2003.

Döll, P. and Lehner, B.: Validation of a new global 30-min drainage direction map, J. Hydrol., 258, 214-231, 2002.

EEA: Sustainable water use in Europe - Part 3: Extreme hydrological events: floods and droughts, Environmental issue report No 21, European Environment Agency, Copenhagen, 2001.

EM-DAT: The OFDA/CRED International Disaster Database, www.em-dat.net, Université Catholique de Louvain, Brussels, Belgium, 2007.

Fleig, A. K., Tallaksen, L. M., Hisdal, H., and Demuth, S.: A global evaluation of streamflow drought characteristics, Hydrol. Earth Syst. Sci., 10, 535-552, 2006,

http://www.hydrol-earth-syst-sci.net/10/535/2006/.

Gottschalka, L., Tallaksena, L. M., and Perzynab, G.: Derivation of low flow distribution functions using recession curves, J. Hydrol., 194, 239-262, 1997.

GRDC: Long Term Mean Monthly Discharges and Annual Characteristics of Selected GRDC Stations, The Global Runoff Data Centre, Koblenz, Germany, 2004.

Guha-Sapir, D., Hargitt, D., and Hoyois, P.: Thirty years of natural disasters 1974-2003: The numbers, Presses Universitaires de Louvain, Louvain-la Neuve, 2004.

Hisdal, H. and Tallaksen, L. M. (Eds.): Drought event definition, ARIDE Tech. Report no. 6, University of Oslo, Oslo, Norway, 2000.

IACWD Interagency Advisory Committee on Water Data: Guidelines for Determining Flood Flow Frequency: Bulletin 17B, U.S. Geological Survey, Office of Water Data Coordination, Reston, VA, 1982.
IEA: Australian rainfall and runoff: a guide to flood estimation, Institution of Engineers, Australia, Barton, ACT, 1998.

IPCC: Climate Change 2001: Synthesis Report, A Contribution of Working Groups I, II, and III to the Third Assessment Report of the Intergovernmental Panel on Climate Change, edited by: Watson, R. T. and the Core Writing Team, Cambridge University Press, Cambridge, United Kingdom, and New York, NY, USA, 398 pp., 2001.

IPCC: Special Report on Emission Scenarios, Intergovernmental Panel on Climate Change, Cambridge University Press, Cambridge, UK, 2000.

Kite, G. W.: Frequency and Risk Analysis in Hydrology, Water Resources Publications, Fort Collins, CO, 1977.

Lehner, B., Döll, P., Alcamo, J., Henrichs, H., and Kaspar, F.: Estimating the impact of global change on flood and drought risks in Europe: a continental, integrated analysis, Climatic Change 75, 273-299, 2006.

Madsen, H., Rasmussen, P. F., and Rosbjerg, D.: Comparison of annual maximum series and partial duration series methods for modeling extreme hydrologic events, Water Resour. Res., 33, 747-757, 1997.

McGraw-Hill: Dictionary of Environmental Science, The McGrawHill Companies, Inc., USA, 2003.

Mitosek, H. T., Strupczewski, W. G., and Singh, V. P.: Three procedures for selection of annual flood peak distribution, J. Hydrol., 323, 57-73, 2006.

New, M., Hulme, M., and Jones, P. D.: Representing twentieth century space-time climate variability: Part II: Development of 1901-96 monthly grids of surface climate, J. Climate, 13, 22172238, 2000.

Palmer, W: Meteorological drought, Research Paper 45, US Weather bureau, Washington D.C., USA, 1965.

Rao, A. R. and Hamed, K.: Flood Frequency Analysis, CRC, West Palm Beach, p. 350, 2000.

Roeckner, E., Arpe, K., Bengtsson, L., Christoph, M., Claussen, M., Dümenil, L., Esch, M., Giorgetta, M., Schlese, U., and Schulzweida, U.: The atmospheric general circulation model ECHAM-4: model description and simulation of present-day climate Max-Planck Institute for Meteorology, Report No. 218, Hamburg, Germany, 90 pp., 1996.

Stahl, K. and Demuth, S.: Linking streamflow drought to the occurrence of atmospheric circulation pattern, Hydrolog. Sci. J., 44(3), 467-482, 1999.

Stedinger, J. R., Vogel, R. M., and Foufoula-Georgiou, E.: Frequency analysis of extreme events, in: Handbook of Hydrology, edited by: Maidment, D. R., McGraw-Hill, New York, 20 pp., 1993.

Tate, E. L. and Freeman, S. N.: Three modelling approaches for seasonal streamflow droughts in southern Africa: The use of censored data, Hydrol. Sci. J., 45, 1, 27-42. 2000

UNICEF: http://www.unicef.org/drought/, updated 19 May 2000, accessed 31 January 2007.

Woo, M. K. and Tarhule, A.: Stream flow droughts of Northern Nigerian rivers, Hydrolog. Sci. J., 35(1), 19-34, 1994.

Wilhite, D. A.: Drought Volume I - A Global Assessment, Routledge, New York, USA, 2000.

WMO - World Meteorological Organization: WMO Technical Note 138, Report of the CagM Working Group on the Assessment of Drought, Geneva, Switzerland, 1975. 